\title{
Genetic Diversity Study in Relation to Yield and Quality Traits in Little Millet (Panicum miliare L.)
}

\author{
Savankumar N. Patel ${ }^{1 *}$, Harshal E. Patil ${ }^{2}$, S. P. Patel ${ }^{1}$ and U. M. Patel ${ }^{1}$ \\ ${ }^{1}$ Department of Genetics and Plant Breeding, N. M. College of Agriculture, Navsari \\ Agricultural University, Navsari-396 450, Gujarat, India \\ ${ }^{2}$ Associate Research Scientist (PB), Hill Millet Research Station, Navsari Agricultural \\ University, Waghai (The Dangs)-394 730, India
}

*Corresponding author

\section{Keywords}

Little millet, Genetic diversity, Multivariate analysis, $D^{2}$ statistics

Article Info

Accepted:

20 May 2018

Available Online:

10 June 2018

\section{A B S T R A C T}

To conduct a successful breeding programme knowledge of genetic divergence is of prime importance for selection of genetically divergent parents from the available germplasm before taking up hybridization programme and the multivariate analysis is an important statistical tool through which we can harness genetic divergence present in the available germplasm. The experiment was conducted with 32 germplasm accessions of little millet to study genetic diversity for yield and yield contributing traits at Hill Millet Research Station, Waghai, The Dangs in a randomize block design. The observations for sixteen morphological and biochemical characters were recorded. Thirty two genotypes of little millet were grouped into seven clusters. The composition of clusters in the present study indicated that a maximum number of diverse genotypes ( 10 genotypes) appeared in cluster II followed by cluster I (9 genotypes), cluster III (7 genotypes), cluster VII (3 genotypes) while other three clusters (IV to VI) were composed of single genotype. The inter-cluster distance (D) ranged from 5.85 to 16.68 . The maximum inter-cluster distance $(\mathrm{D}=16.68)$ was observed between cluster II and VI followed by those between cluster II and V (D= 15.97). The intra-cluster distance within cluster IV, V, VI was zero (0) because these clusters were composed of only single genotype. Analysis corroborated the absence of relationship between geographic origin and genetic diversity, as genotypes from the different area grouped into same clusters and the genotypes of same area were grouped in the different clusters. Therefore, breeder must evaluate their material for genetic diversity and should not merely depend on their geographical origin.

\section{Introduction}

Little millet belongs to the family Poaceae, sub-family Panicoideae and the tribe Paniceae (Rachie, 1975). Little millet was domesticated in the Eastern Ghats of India occupying a major portion of diet amongst the tribal people and spread to Sri Lanka, Nepal, and Myanmar (De Wet et al.,). Little millet (Panicum miliare L.) is grown in India under various agroecological situations and commonly known as samai, samo, moraio, vari, kutki. India is well known for its rich agro-biodiversity and prime contributor with 473 accessions (Upadhyaya 
et al., 2016) In India, little millet having 1.42 lakh tones of production. In Gujarat, little millet is cultivated in an area of 10,634 hectares with 9,526 tonnes of production having the productivity of $896 \mathrm{~kg} / \mathrm{ha}$ (Anonymous, 2015). The area under this crop is mainly concentrated in the districts of The Dangs, Valsad, Navsari of South Gujarat and Panchmahal of middle Gujarat.

Little millet is a hardy crop which can withstand drought better than most of other cereal crops and water logging to a certain degree, also. Besides India, it is cultivated in Nepal and Western Burma. The potentiality of little millet has not been exploited in India and the yield levels are very low there by indicating a greater scope for exploitation of this millet under Indian condition. In India, little millet growing states are Karnataka, Tamil Nadu, Odisha, Madhya Pradesh, Chattisgarh, Jharkhand, Andhra Pradesh, Uttarakhand, Maharashtra and Gujarat. In Gujarat, generally little millet crop is grown in hilly tract of The Dangs and Valsad district and locally known as "Vari or Moraio". The productivity of little millet is low due to poor soil fertility and age-old cultivation methods.

The yield potential of little millet is low and plagued with a number of genetical and morphological reasons. Though, the crop has been important over centuries, more concentrated research efforts are geared in recent years to evolve improved varieties and develop production technology.

To conduct a successful breeding programme knowledge of genetic divergence is of prime importance and the selection of genetically divergent parents from the available germplasm and breeders greatly depend upon the nature and magnitude of genetic variance of the characters under consideration and interrelationship among them before taking up hybridization programme.
In present study we use Mahalanobis's $\mathrm{D}^{2}$ statistics which is useful tool in quantifying the degree of divergence between biological populations at genetic level and to assess the relative contributions of different components to the total divergence in isolating suitable parents.

\section{Materials and Methods}

The experiment was conducted at Hill Millet Research Station, Navsari Agricultural University, Waghai (The Dangs) using 32 genotypes of little millets in randomized block design with three replications. The gross plot is divided into three blocks which were taken as a replications while the blocks are further divided into equal 32 plots. Five randomly selected plants from each genotypes in each replications were used to record observations for morphological characters. Data were recorded on total 16 morphological and biochemical traits viz., days to $50 \%$ flowering, days to maturity, zinc content (mg), plant height at maturity $(\mathrm{cm}), 1000$ seed weight $(\mathrm{g})$, fiber content $(\%)$, number of productive tillers per plant, Protein content (\%), number of branches per panicle, ash content $(\%)$, Panicle length $(\mathrm{cm})$, fat content $(\%)$, grain yield per plant $(\mathrm{g})$, calcium content (mg), straw yield per plant (g), iron content $(\mathrm{mg})$. Data were analyzed to estimate genetic divergence by multivariate analysis using Mahalanobis (1936) $\mathrm{D}^{2}$ statistic as described by Rao (1952). On the basis of $\mathrm{D}^{2}$ values genotypes were grouped into different clusters according to Tocher's method given by Rao (1952).

\section{Results and Discussion}

$\mathrm{D}^{2}$ statistics, is an important tool multivariate developed by Mahalanobis (1936) to classify the genotypes into different groups based on genetic divergence between them. The basic idea behind formation of clusters is to get the 
intra and inter cluster distances which is very helpful in selection of parents with diverse origin.

\section{Distribution of genotypes into clusters}

Thirty two genotypes of little millet were grouped into seven clusters by Tocher's method. The composition of clusters is given in Table 1. The results indicated that a maximum number of diverse genotypes (10 genotypes) appeared in cluster II followed by cluster I (9 genotypes), cluster III (7 genotypes), cluster VII (3 genotypes) while other three clusters (IV to VI) were composed of single genotype.

Genotypes of different geographical areas were fall in one group and also the genotypes of the same geographical area were clubbed into different groups indicating there is no formed relationship between geographical diversity and genetic diversity.

Many workers have been arrived at similar conclusion for example Dhagat and Singh (1983); Sheriff and Shivashankar (1992); Satish et al., (2007); Chemeda and Gemechu (2010); Kumar et al., (2010); Sindhe et al., (2013); Suryanarayan et al., (2014); Vasadia (2015) and Devaliya et al., (2017).

\section{Intra and inter cluster distances}

The intra and inter cluster distances (D) between all possible pairs of seven clusters were computed and presented in Table 1 as well as shown in figure 1. A study of the data revealed that the inter-cluster distance (D) ranged from 5.85 to 16.68 . The maximum inter cluster distance $(\mathrm{D}=16.68)$ was observed between cluster II and VI followed by those between cluster II and V ( $\mathrm{D}=15.97)$. The minimum intercluster distance $(\mathrm{D}=5.85)$ was observed between cluster $\mathrm{V}$ and VI followed by the cluster IV and VII ( $\mathrm{D}=9.37)$.
Intra-cluster distance (D) ranged from 0.00 to 10. At intracluster level, cluster VII had the highest intra cluster distance $(\mathrm{D}=10)$ followed by cluster I $(\mathrm{D}=7.34)$ which involve 3 and 9 genotypes, respectively. The intracluster distance within cluster IV, V, VI was zero (0) because these clusters were composed of only single genotype.

From the results of this investigation, it was found that number of cluster contained at least one genotype with the desirable traits, which ruled out the possibility of selecting directly one genotype for immediate use.

Therefore, hybridization between the selected genotypes from divergent clusters is essential to judiciously combine all the targeted traits. From the results, it could be concluded that intercrossing genotypes from cluster IV, V and cluster VI might results in wide array of variability for exercising effective selection.

\section{Cluster means for different characters}

Cluster mean for all the sixteen characters are presented in Table 3. The results clearly indicated appreciable difference among cluster means for most of the characters.

As far as cluster means are concerned, Cluster I had the highest mean values for the characters panicle length (36.69) and calcium content (245.15) while, it had minimum cluster mean for number of branches per panicle (6.17). cluster II had the highest mean values for the characters days to $50 \%$ flowering (116.47), number of productive tillers per plant (8.55), grain yield per plant (7.59), days to maturity (141.07), protein content (5.98) while, it had minimum cluster mean for ash content (2.51). Cluster III had the highest mean values for the character 1000 grain weight (2.10) while it had minimum cluster mean for straw yield per plant (14.47) and zinc content (6.18). 
Table.1 The distribution of thirty two genotypes of little millet into seven different clusters on the basis of Mahalanobis's $\mathrm{D}^{2}$ statistics

\begin{tabular}{|c|c|c|}
\hline Cluster & $\begin{array}{c}\text { No. of } \\
\text { genotypes }\end{array}$ & Genotypes \\
\hline Cluster I & 9 & GPUL 2, GPUL 8, GPUL 22,GPUL 24, GPUL 27, GPUL 11, KOPLM 18, KOPLM 36, KOPLM 31 \\
\hline Cluster II & 10 & WV 32, WV 37, WV 56, WV 64, WV 78, WV 82, WV 112, WV 125, WV 167, KOPLM 48 \\
\hline Cluster III & 7 & KOPLM 37, KOPLM 30, VR 49, VR 52, VR 56, VR 37, VR 39 \\
\hline Cluster IV & 1 & KOPLM 33 \\
\hline Cluster V & 1 & VR 45 \\
\hline Cluster VI & 1 & VR 41 \\
\hline Cluster VII & 3 & GPUL 7, GPUL 16, WV 28 \\
\hline
\end{tabular}

Table.2 Average intra and inter cluster distance for thirty two genotypes of little millet

\begin{tabular}{|c|c|c|c|c|c|c|c|}
\hline Cluster & Cluster I & Cluster II & Cluster III & Cluster IV & Cluster V & Cluster VI & Cluster VII \\
\hline Cluster I & 7.34 & 11.71 & 10.13 & 9.82 & 11.53 & 10.09 & 10.51 \\
\hline Cluster II & & 8.73 & 13.75 & 9.81 & 15.97 & 16.68 & 10.97 \\
\hline Cluster III & & & 9.59 & 11.54 & 11.63 & 10.87 & 13.28 \\
\hline Cluster IV & & & & 0.00 & 12.61 & 12.87 & 9.37 \\
\hline Cluster V & & & & & 0.00 & 5.85 & 12.35 \\
\hline Cluster VI & & & & & & 0.00 & 13.08 \\
\hline Cluster VII & & & & & & & 10.00 \\
\hline
\end{tabular}


Table.3 Cluster means for sixteen characters in thirty two genotypes of little millet

\begin{tabular}{|c|c|c|c|c|c|c|c|c|}
\hline Cluster & DF & PH & NOT & NOB & PL & GY & SY & DM \\
\hline Cluster I & 106.89 & 168.63 & 6.82 & 6.17 & 36.69 & 5.69 & 16.70 & 131.70 \\
\hline Cluster II & 116.47 & 168.69 & 8.55 & 7.27 & 35.07 & 7.59 & 20.38 & 141.07 \\
\hline Cluster III & 97.38 & 148.60 & 6.61 & 7.46 & 29.07 & 3.27 & 14.47 & 132.90 \\
\hline Cluster IV & 114.00 & 172.00 & 4.46 & 7.26 & 32.67 & 4.61 & 23.92 & 134.33 \\
\hline Cluster V & 92.67 & 147.69 & 4.73 & 7.75 & 28.22 & 3.08 & 14.68 & 133.00 \\
\hline Cluster VI & 96.00 & 169.27 & 4.83 & 7.76 & 26.42 & 2.94 & 15.98 & 134.00 \\
\hline Cluster VII & 104.67 & 173.34 & 7.57 & 6.59 & 35.17 & 6.55 & 17.95 & 131.11 \\
\hline Cluster & TW & PR & ASH & FAT & $\mathbf{C a}$ & $\mathrm{Fe}$ & Zn & FIB \\
\hline Cluster I & 1.61 & 4.51 & 2.92 & 3.55 & 245.15 & 6.82 & 7.16 & 8.56 \\
\hline Cluster II & 1.96 & 5.98 & 2.51 & 3.41 & 210.02 & 6.91 & 6.79 & 7.25 \\
\hline Cluster III & 2.10 & 4.66 & 3.00 & 3.43 & 240.10 & 6.26 & 6.18 & 8.97 \\
\hline Cluster IV & 1.58 & 5.43 & 2.79 & 2.70 & 190.50 & 6.74 & 6.50 & 8.43 \\
\hline Cluster V & 1.62 & 4.53 & 3.40 & 3.98 & 157.88 & 6.69 & 7.40 & 8.70 \\
\hline Cluster VI & 1.31 & 4.37 & 3.70 & 3.78 & 223.54 & 5.90 & 7.30 & 9.03 \\
\hline Cluster VII & 1.50 & 5.39 & 2.53 & 3.31 & 190.09 & 6.97 & 7.04 & 6.37 \\
\hline
\end{tabular}

Where,

\begin{tabular}{|c|c|c|c|}
\hline $\mathrm{DF}=$ Days to $50 \%$ flowering & GY= Grain yield per plant $(\mathrm{g})$ & $\begin{array}{l}\text { ASH= Ash content } \\
(\%)\end{array}$ & $\begin{array}{l}\text { FIB= Fiber content } \\
(\%)\end{array}$ \\
\hline $\begin{array}{l}\text { NOT= Number of productive tillers } \\
\text { per plant }\end{array}$ & DM= Days to maturity & $\begin{array}{l}\mathrm{Ca}=\text { Calcium content } \\
(\mathrm{mg})\end{array}$ & \\
\hline $\begin{array}{l}\mathrm{NOB}=\text { Number of branches per } \\
\text { panicle }\end{array}$ & TW= 1000 seed weight $(\mathrm{g})$ & $\mathrm{Fe}=$ Iron content $(\mathrm{mg})$ & \\
\hline PL $=$ Panicle length $(\mathrm{cm})$ & $P R=$ Protein content $(\%)$ & $\begin{array}{l}\mathrm{Zn}=\text { Zinc content } \\
(\mathrm{mg})\end{array}$ & \\
\hline
\end{tabular}


Table.4 Contribution of sixteen characters under study towards total divergence

\begin{tabular}{|c|c|c|c|}
\hline Sr. No. & Character & No. of time ranked first & $\%$ contribution towards divergence \\
\hline 1 & Days to $50 \%$ flowering & 0 & 0.00 \\
\hline 2 & Plant height at maturity $(\mathrm{cm})$ & 0 & 0.00 \\
\hline 3 & Number of productive tillers per plant & 27 & 5.44 \\
\hline 4 & Number of branches per panicle & 0 & 0.00 \\
\hline 5 & Panicle length (cm) & 0 & 0.00 \\
\hline 6 & Grain yield per plant (g) & 65 & 13.10 \\
\hline 7 & Straw yield per plant (g) & 6 & 1.21 \\
\hline 8 & Days to maturity & 0 & 0.00 \\
\hline 9 & 1000 seed weight (g) & 40 & 8.06 \\
\hline 10 & Protein content (\%) & 8 & 1.61 \\
\hline 11 & Ash content (\%) & 76 & 15.32 \\
\hline 12 & Fat content & 47 & 9.48 \\
\hline 13 & Ca content & 121 & 24.40 \\
\hline 14 & Fe content & 16 & 3.23 \\
\hline 15 & Zn content & 34 & 6.85 \\
\hline \multirow[t]{2}{*}{16} & Fiber content & 56 & 11.29 \\
\hline & Total & 496 & 100 \\
\hline
\end{tabular}


Fig.1 Clustering pattern in little millet genotypes based on morphological character

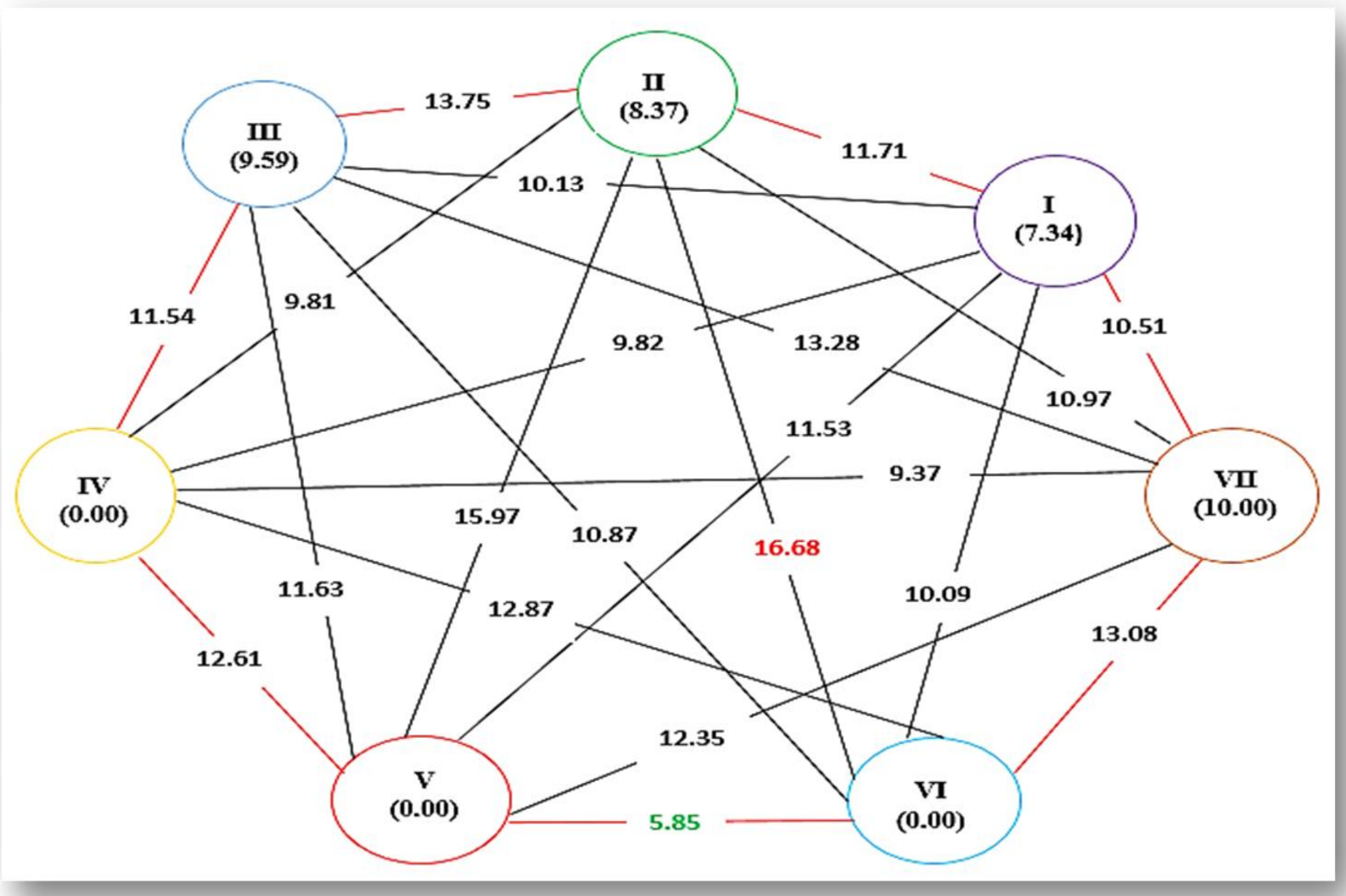


Fig.2 Contribution (\%) of various traits of little millet towards divergence
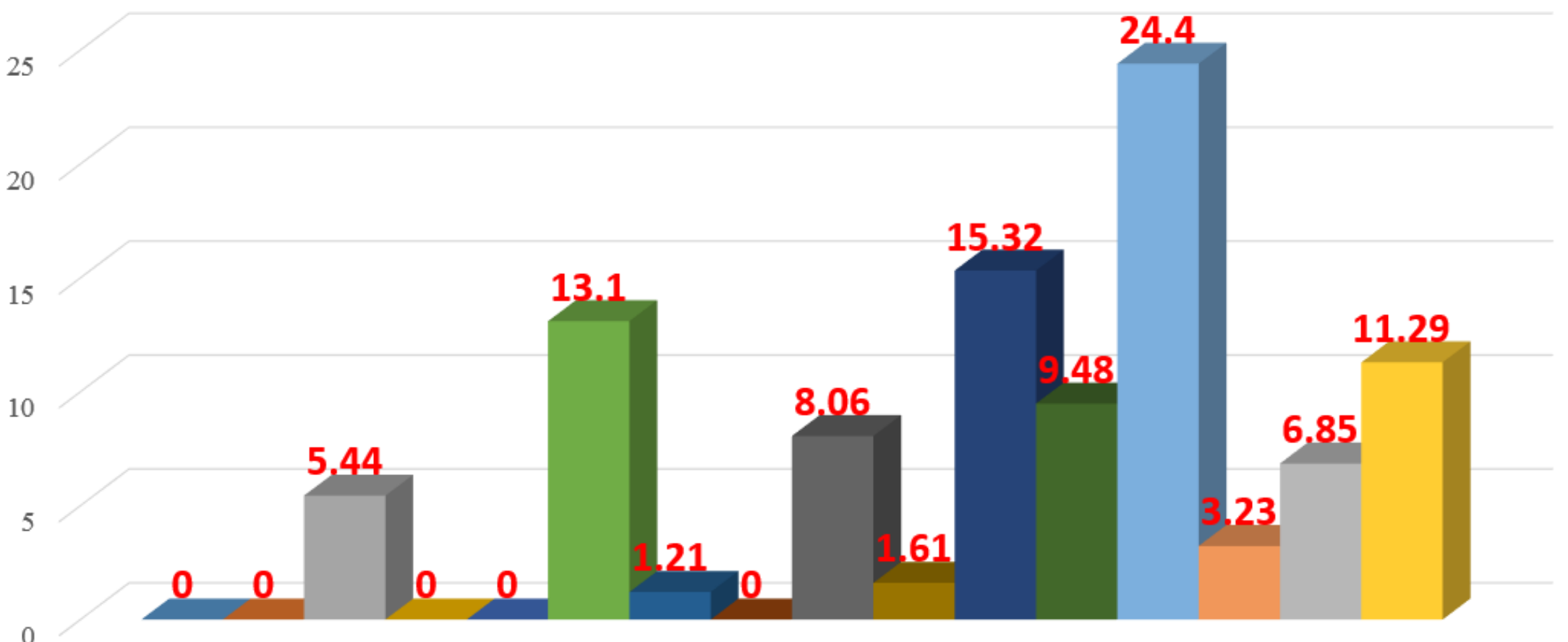

0

$\%$ contriburion towards divergence

Where,

\begin{tabular}{|c|c|c|c|}
\hline $\mathrm{DF}=$ Days to $50 \%$ flowering & GY= Grain yield per plant $(\mathrm{g})$ & $\mathrm{ASH}=$ Ash content $(\%)$ & $\begin{array}{c}\text { FIB }=\text { Fiber content } \\
(\%)\end{array}$ \\
\hline PH= Plant height at maturity $(\mathrm{cm})$ & SY= Straw yield per plant $(\mathrm{g})$ & FAT $=$ Fat content $(\%)$ & \\
\hline $\begin{array}{l}\text { NOT }=\text { Number of productive tillers } \\
\text { per plant }\end{array}$ & DM= Days to maturity & $\begin{array}{l}\mathrm{Ca}=\text { Calcium content } \\
(\mathrm{mg})\end{array}$ & \\
\hline $\begin{array}{l}\text { NOB }=\text { Number of branches per } \\
\text { panicle }\end{array}$ & TW= 1000 seed weight $(\mathrm{g})$ & $\mathrm{Fe}=$ Iron content $(\mathrm{mg})$ & \\
\hline PL= Panicle length $(\mathrm{cm})$ & $\mathbf{P R}=$ Protein content $(\%)$ & $\mathrm{Zn}=$ Zinc content $(\mathrm{mg})$ & \\
\hline
\end{tabular}


Cluster IV had the highest mean values for straw yield per plant (23.92) while it had minimum cluster mean for number of productive tillers per plant (4.46) and fat content (2.70). Cluster $\mathrm{V}$ had the highest mean values for fat content (3.98) and zinc content (7.04) while it had minimum cluster mean for days to $50 \%$ flowering (92.67), plant height at maturity (147.69) and calcium content (157.88). Cluster VI had the highest mean values for number of branches per panicle (7.76), ash content (3.70) and fiber content (9.03) content while it had minimum cluster mean for panicle length (26.42), grain yield per plant (2.94), 1000 grain weight (1.31), protein content (4.37), and iron content (5.9). Cluster VII had the highest mean values for plant height at maturity (173.34) and iron content (6.97) content while it had minimum cluster mean for days to maturity (131.11) and fiber content (6.37).

\section{Contribution of various characters towards genetic divergence}

The characters viz., calcium content, ash content and grain yield per plant appeared to be the most important traits contributing maximum towards genetic divergence, so these characters should be given due importance (Table 4. and Figure 2). Inter cluster distances indicated that the accessions included in the diverse clusters would be used in further crop improvement programme.

\section{References}

Anonymous 2014-2015. Annual progress report. Project Coordinating Unit, AICRP on Small Millets, GKVK. Bangalore.

Devaliya, S. D., Singh, M. and Intawala, C. G. 2017. Genetic divergence studies in finger millet (Eleusine coracana (L.) Gaertn.) International Journal of
Current Microbiology and Applied Sciences, 6(11): 2319-7706.

Dhagat, N. K. and Singh, S. P. 1983. Genetic Divergence in Kodo Millet, Indian J. Genet., 43: 168-172.

Kumar, D., Tyagi, V., Ramesh, B., and Pal, S. 2010. Genetic diversity in finger millet (Elusine coracana L.). Crop Improvement, 37(1): 25-28.

Mahalanobis's P.C. 1936. On the generalized distance in statistics. Proc. Nat. Inst. Sci., (India). 2: 49-55.

Rachie, K. O. 1975. The millets. Importance, utilization and outlook. Int. Crops Res. Inst. Semi-Arid Tropics (ICRISAT publication). Hyderabad, India.

Rao, C. R. 1952. "Advanced Statistical Methods in Biometrical Research", John Willy and Sons, Inc., New York, pp. 390.

Satish, D., Shanthakumar, G., Salimath, P. M. and Gangaprasad, S. 2007. Genetic diversity for productivity traits in finger millet. International J. Plant Sci., 2(2): 34-37.

Sheriff, R. A. and Shivashankar, G. 1992. Genetic divergence in Foxtail Millet (Setaria italica L.). Indian J. Genet., 52(1): 29-32.

Shinde, S. R., Desai, S. V. and Pawar, R. M. 2013. Genetic diversity pattern in finger millet (Eleusine coracana (L.) Gaertn).Electronic Journal of Plant Breeding, 4(3): 1242-1245.

Suryanarayana, L., Sekhar, D. and Rao, V. D. 2014. Genetic variability and divergence studies in finger millet (Eleusine coracana (L.) Gaertn.). International Journal of Current Microbiology and Applied Sciences, 3 (4): 931-936.

Upadhyaya, H. D., Vetriventhan, M., Dwivedi, S. L., Pattanashetti, S. K., and Singh, S. K. 2016. "Proso, barnyard, little, and kodo millets," in Genetic and Genomic Resources for Grain Cereals 
Improvement. Frontiers in plant science, 321-343.

Vasadia, A. H. 2015. Assessment of Genetic Diversity in little millet. (Panicum miliare (L.) M.Sc. Thesis submitted to Navsari Agricultural University, Navsari.

\section{How to cite this article:}

Savankumar N. Patel, Harshal E. Patil, S. P. Patel and Patel U. M. 2018. Genetic Diversity Study in Relation to Yield and Quality Traits in Little Millet (Panicum miliare L.). Int.J.Curr.Microbiol.App.Sci. 7(06): 2702-2711. doi: https://doi.org/10.20546/ijcmas.2018.706.319 